
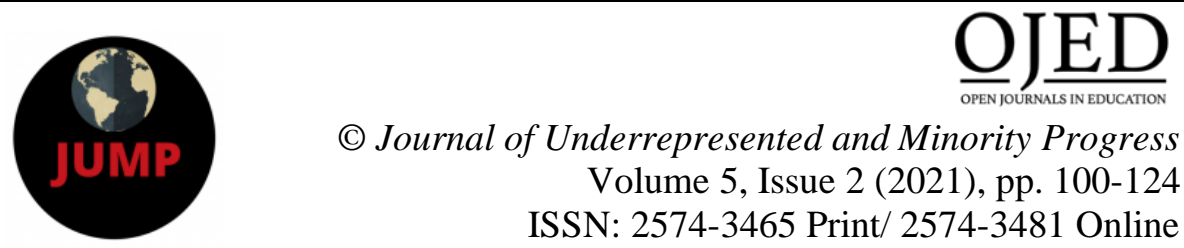

(C) Journal of Underrepresented and Minority Progress

Volume 5, Issue 2 (2021), pp. 100-124 ISSN: 2574-3465 Print/ 2574-3481 Online http://ojed.org/jump

\title{
Relevance of the Historically Black Colleges and University (HBCU) and Land Grant Model for Inclusive Transformation in Federal Nepal
}

Purna Bahadur Nepali, Kathmandu University, Nepal

Uttam Gaulee, Morgan State University, USA

Prakash Baral, Ministry of Land Management, Agriculture, Cooperatives and Poverty Alleviation, Gandaki Province, Nepal

Suwas Paudel, Value Chain Development Project, Nepal

Santosh Khanal, Institute of Agriculture and Animal Science, Nepal

\begin{abstract}
The institutionalization of federalism has created a space for Nepal with an opportunity to transform into a more inclusive and equitable society with a vibrant economy. Towards this transformation, adoption of the elements of Land Grant model in higher education system of Nepal can be a key to break the long-stagnant agrarian economy characterized by persistent inequality, structural poverty and stunted economic growth. This paper attempts to present a perspective analysis of US-based Land Grant Universities/ Institutions (LGUs/LGIs) and Historically Black Colleges and University $(H B C U)$ mission and its possible implications in the agrarian landscape with priority laid on the inclusive agrarian transformation of Nepal through consideration of these models in the spirit of social inclusion and agrarian justice as envisaged in the constitutional provisions, policies and the structural features of country's stagnant economy.
\end{abstract}


The grand design of American higher education in the context of the initiatives of LGUs and HBCUs could be the eye-opening lesson for the academic institutions, especially, the new provincial universities of Nepal for engaging the community beyond academic function, building a strong university-community partnership, relationship and aligning their educational endeavors toward optimizing the use of available natural and human resources in society. A community based inclusive transformation could be coordinated and aligned with the local, provincial and national governments and leaders in line with their political and social aspirations so that the local resources could be leveraged to catalyze local initiatives and promote indigenous innovation while consolidating the commitment to social diversity and inclusion for overall societal transformation of federal states of Nepal through concerted higher education reforms in lines of $L G U$ and HBCUs.

Keywords: Land Grant University, Inclusive transformation, Provincial University, Social Diversity and Inclusion

\section{COBTEXT \& BACKGROUND}

With the promulgation of Constitution of Nepal in 2015 and the completion of first round of all levels (Federal, Provincial and Local levels) of elections, Nepal has finally institutionalized the federalization process. This has opened the opportunity to formulate policies and initiate developmental efforts from grass-root level with shared and self-rule principles. These mechanisms will need to be geared to achieve the national goals and visions of prosperity, political stability, economic growth and gradual transformation of the nation to middle-income nation by 2030 (NPC, 2016).

The historical struggle and a decade long-armed conflict on the part of people that experience long-standing denial of rights has created a radical political change in the country. This change has been significant for restoration of people's rights and has resulted in high aspirations among people for overall inclusive socio-economic and cultural transformation. As a reflection of popular aspirations, the constitution has embodied provisions for inclusion and devolution of power and authority to province and local governments focusing on two main underlying principles: Principle of subsidiarity and Principle of equity and inclusion. While the principle of subsidiarity advocates for the service delivery through the lowest possible tier 
of government close to the target group, the principle of equity and inclusion focuses on uplifting the status and livelihood of the underserved backward communities, marginalized, and disadvantaged people through specialized through targeted programs of governments, so that no-one would be devoid of the benefits of development and the federalization process (Council of Ontario Directors of Education, 2014). Based on these principles, it is a significant challenge for new central and federal state governments to sketch the road map for overall state and societal restructuring, reorientation of the existing government apparatus to address the concerns of poor and marginalized communities in a rural landscape and streamline the overall process of socio-political and economic transformation. It is essential to cultivate the sense of responsibility among multi-stakeholders including civil society and people to manage and engage them in the federalization process for addressing the issues of social justice and prosperity, and overall agrarian transformation in each of the seven newly formed federal states.

Specifically, Articles 25, 36, 40 and 51 of the Constitution guarantee the people's rights over land, natural resources, and the right to food and to engage in agriculture in alignment with the public interest. The Constitution directs the States to protect the people's rights through legislation. The provisions stipulated in the constitution reflect the principle of a mixed economy with a socialist orientation, which aims for overall socio-political and economic transformation. Prof. John Dewey, in his seminal work 'Education for social transformation', had advocated the role of education and educational institutions in enabling individuals to grasp the complexity and broader implications of social issues and empower and engage them for developing real solutions for those issues, thus highlighting the necessity of education for overall transformation process. In this context, Article 57 (Distribution of state power) Schedule 6 of the constitution has mentioned the concept of State universities, higher education, and libraries for educating and empowering the people for their engagement in overall social transformation and ever-lasting sustainable peace.

Land-Grant Model is not a new concept in agricultural education institutions, which are the diverse group of college and universities, mandated and supported federally for providing practical education and programs of teaching, extension and research, while maintaining a close relationship with neighboring communities to assess and solve their real field problems for fostering the agricultural development and hence, pave a pathway for inclusive rural transformation. In this regard, this paper attempts to address specific questions regarding the agricultural education institutions in Nepalese context, such as: 
- What aspect(s) of the LGU/HBCU models could be appropriate and relevant to Nepal's condition?

- What could be a new direction for the provincial universities and agricultural institutions in Nepal for inclusive agrarian and rural transformation?

- What could be the role of the provincial and local governments for strengthening the LGUs and LGIs at local levels?

To narrow the scope from the comprehensive federalization process to a specific sector of change, this paper illustrates the general methods of inclusive rural transformation through the application of the lessons of Land Grant University models from the US and other parts of the world at federal, provincial and local levels.

\section{Lessons learnt from Global and Local Level Practices}

\subsection{Land-Grant University and HBCU Models and their relevance to} the Nepalese context

Established via Morrill Act (1862) by President Abraham Lincoln, the Land Grant University System provides the grant of federal land to any state willing to establish a public university to serve the community with experiential learning beyond classical teaching and research, and fosters academic excellence, diversity, and inclusion. Similarly, $H B C U s$ were established through second Morrill Act in 1890 to educate and empower the enslaved African Americans and to address their historical social and racial injustice (disfranchisement and segregation). These HBCUs served as islands of hope for the overall empowerment of black communities and social emancipation (separate but equal schools for black communities). Furthermore, in 1994, yet another set of institutions were added to advance social justice through higher education: Native American Tribal colleges and Hispanic serving institutions.

Consolidating the efforts of all of these institutions towards greater social justice, the International Association of Public and Land-grant Universities (APLU), a voluntary association of public research universities, land-grant institutions, state university systems, and other affiliated organizations in the US, Canada, and Mexico, is committed in advancing the federal policies to strengthen public universities for community development and promote diversity and inclusion by exercising the principles of equal access and equal opportunity in education and employment through the development of corresponding policies and initiatives. 
Undergirding the fundamental principles of these institutions, the extraordinary contributions of global icons Martin Luther King and W.E.B. $\mathrm{Du}$ Bois for civil and political rights are given their due considerations to address historical racial injustice and inequality as well as their subsequent socio-political and economic empowerment issues. Also, the Cooperative extensions with $L G U$ via National Food Security Institute are technically designed for black farmers' empowerment, workers' rights, and economic justice (e.g. organizing black farmers and the cooperative movement in Mississippi and Georgia State).

Hence, LGU has contributed a plethora of initiatives and works from established universities. Beyond classical teaching/academic excellence, it contributes community-college relations, research outreach, and cooperative functions to serve African-American farmers and their social and racial justice, recently addressing the land and agricultural concerns of the $21^{\text {st }}$ century in contemporary food and economic crisis, considering tenure security, property rights and importance of smallholders. Moreover, HBCUs have provided an atmosphere for social change, social movement/emancipation, and community development vis-à-vis the establishment of academic institutions for teaching and community service. In the last 16 decades, the LGU model had a transformative effect and brought about remarkable changes towards overall rural US, Mexico, and Canada, and beyond. The US government celebrated the $150^{\text {th }}$ Anniversary of the LGU model in 2012.

One of the major strengths of the LGU model is its focus on the integration of education with research and extension. Particularly because Nepal's weak linkage between research, extension and education has been well documented (Jaishi et. al, 2020), adoption of the LGU model in the Nepalese context could address the systemic "bottlenecks" in national agricultural technology systems limiting their effectiveness to agricultural development. Various evidences in the US, Mexico and Canada have already shown that a strong linkage among these three components play significant role in empowering the backwards and marginalized and fostering the community level participation for overall transformation process, there is a need of such formal linkage mechanism to connect these components in Nepal. Adapting LGU model educational institutions could address this linkage gap and foster the inclusive agrarian and social transformation through participation and inclusion of diversified communities including the disadvantaged and marginalized groups at local levels. 


\subsection{Some Exemplary Interventions at Local Levels relevant to Nepalese context}

Out of the many concrete examples of local level interventions in the US, we illustrate a few below in order to illustrate the contributions of LGUs to community development and inclusive transformation models:

Fort Valley State University (FVSU) is one of the HBCUs in line with the 1890s' land grant institutions devoted to serving enslaved African American farmers and minority people in 30 counties of Georgia State and boasts a number of programs demonstrating academic excellence.

FVSU is charged with a mission to provide an educational opportunity for all through innovative scientific research and Cooperative Extension programs that are stakeholder-driven and respond to emerging issues related to food, agriculture, and livestock sciences. Among the various programs, Land Owners Initiatives for Forestry Education (LIFE) is one of the key projects implemented in Fort Valley.

"LIFE project addresses the needs of unserved farmers and landowners through enabling farmers with distinct estate planning in the federal cost-share program. It attempts to increase outreach, awareness, and technical assistance for minority and limited resources forest landowners about land management and its value. Key components are GIS-based map and database, forest management and protection strategies, and estate planning approaches. Its target groups are minority/unserved African American farmers and smallholders. As of now, it served 1300 landowners and 10 estate planning, clients. Out of the total, more than 92 African American farmers, $6 \%$ white, and $2 \%$ others benefited from the project. Among them, $35 \%$ were female farmers" (FVSU, 2012).

University of Georgia, one of the very first Land Grant Academic Institutions established in 1862, aims at extending the lifelong learning to Georgia's citizens through unbiased, research-based education in agriculture, the environment, communities, youth, and families, as well as tackling some of the state's and world's grand challenges from combating diseases and securing a safe food supply to strengthening families, communities and economic growth through its Cooperative Extension service. It is responsible for delivering diverse ranges of community-based extension service to all counties of Georgia and making education work/fit to all Georgians. The main three program areas comprise Agriculture and Natural Resources, Family and Consumer Sciences, and 4-H Youth Development. The Minorities in Agriculture, Natural Resources and Related Sciences Club under the university empowers individuals of under-represented and diverse backgrounds by providing continuing education, peer and professional 
mentor networks and advocacy to access rewarding economic avenues, accomplishment and advancement. It provides them a platform to identify prospective employees who are well-qualified, highly educated, and represent a growing population that hails from various communities, cultures, and backgrounds (MANRSS, 2018).

University of San Diego's Joan B. Kroc School of Peace Studies is another such program that engages the whole faculty and students in developing innovations that help communities address poverty and social injustices, thereby contributing to change in contemporary world. It exposes the wide ranges of issues and promotes experiential learning to create tangible alleviation of poverty, inequality, human rights abuses, humanitarian crises etc. It also believes in innovative vision and critical thinking at the roots of social challenges and injustice, and then seeks to create real change through bold new responses to poverty, inequality, human rights. As a learning outcome, it focuses on knowledge, diverse perspective, critical inquiry, applied learning, communication, and ethical reasoning (University of San Diego, 2018).

University of Massachusetts (UMASS)'s Center for Agriculture, Food and the Environment's cooperative extension is another initiative that provides extension education and community services to all Massachusetts residents. However, they are focused on a common goal, which is to educate and inform individuals, communities and businesses on topics of interest and concern, utilizing the academic resources of UMASS Amherst and other sources. Their intention is to fulfill unmet educational needs of recognized public priority in the linked set of research and outreach interest, including research and integrated-research-and-extension. In addition, UMASS also contributes to various civic society initiatives such as Greater Boston: Food Bank, Healthy Waltham, Community support farm, Urban and Peri-urban agriculture, Community based Land Initiatives, Waltham Land Trust with educational activities (UMASS, 2018).

Brandeis University's International Center for Ethics, Justice, and Public Life provides a platform and an opportunity for faculty, staff, and students for their active and meaningful engagement in state and local level development processes. The Educational Network for Active Civic Transformation (ENACT) is a national program engaging undergraduates at colleges and universities in state-level legislative change by learning to work with legislators, staffers, and community organizations to advance policy. It is becoming a major voice in addressing challenges to American democracy by engaging young people around the country in civic activism built on knowledge, cooperation, justice, and integrity. Students learn through direct 
engagement in this work, traveling to the state capital, meeting with and lobbying legislators, strategizing with advocacy organizations, and creating outreach materials to advance their chosen issues (Brandies, 2018).

University of New Hampshire leads a Consortium of Universities known as the Sustainability Institute, which has collaboratively introduced New England Food Visions. The collaborative food visions are championed by Food Solutions New England, a network serving as a convener and cultivator of their regional food system. Looking ahead to 2060, the New England Food Vision considers a future in which food nourishes a social, economic, and environmental landscape that supports a high quality of life for everyone, including generations to come and sees farming and fishing as important regional economic forces, forests and waterways cared for sustainably, healthy diets as norms, and access to food valued as a basic human right: progressive realization of policies and practices that promote equitable access to food to all (Anderson et al., 2014).

In addition to the initiatives listed above there are many others advancing similar causes. For example, Rhode Island's Food Policy Council attempts to promote "a more accessible, more equitable, and more sustainable food system in Rhode Island" and advocates for improvements to the local food system to increase and expand its capacity, viability, and sustainability.

In a broader scale, the Black Lives Matter Global Network talks about structural and systemic racism, racial equity and justice as well as about farmers of color and women and military veteran farmers and aims to connect the local struggles of Brandeis students and other scholarly-activists in the Boston area to broader national and global issues that have animated the Black Lives Matter movement.

These exemplary efforts/models have pivotal role in improving equity and equality by taking the education from within boundaries of universities and education institutions to the surrounding communities especially the oppressed and disadvantaged ones through outreach programs and community based inclusive approaches with main motto of "working with them" to address their felt needs and problems related to agriculture, food and rural development and to strengthen their livelihoods, thus overall attempting to promote the agrarian and community development in their territories. Their advocacy for the quality of life for all, especially the oppressed and disadvantaged, their power, freedom, justice, equity and empowerment along with the agrarian and social justice have paved pathway for social emancipation and inclusive transformation. Their focus on the real-life problem solving and preparing the individuals to solve those situations for 
sustainable livelihood helps in building of a prosperous and peaceful society through education. These efforts could be a well-deliberated model for an underdeveloped country like Nepal where, caste, ethnicity, and gender-based discrepancies have weakened social, economic, political, and cultural inclusion. Moreover, higher education is becoming more insensitive towards concurrent social issues and concerns of certain Nepalese communities and societies (Regmi, 2019). Women are receiving inadequate education as compared to men and Dalit women are the most disadvantaged (Central Bureau of Statistics, 2011). Disparities in education are still rampant today as the chances of Dalits and Muslims are most prune to complete basic education. The literacy of Terai Dalit (23.1 percent) compared with that of Terai Brahmin ( 80 percent) gives an idea of the gaping fault lines of existing discriminatory system.

To sum it up, the conventional education system is not addressing vital issues properly and yielding strategy for tackling structural and cultural concerns of Nepalese societies and communities and calls for an innovative educational system, that could foster the social inclusion and sense of equality and belongingness among the diversified groups and communities (caste, class, gender based) to dismantle the chain of discrimination, vulnerability and marginalization and support national peace and cohesion (Ibid), through agrarian and rural development and transformation, leaving no-one behind. The adaptation of the LGU models could play important role in resolving the caste, gender and class-based disparities in Nepal.

\section{Efforts so far in Nepal}

Following the concept of the land-grant university model from US and global experiences, there are some scattered efforts and initiatives in Nepal. Some of them are briefly illustrated below:

- Initiation of Community-based Land Grant Model College under Agriculture and Forestry University in Puranchaur, Kaski

After the grand religious function called 'Mahayagya' organized by Puranchaur Community ("Krishi College Sthapanartha Tadartha Committee Puranchaur, Kaski"), voluntarily donated 50 ropanies ( 2.5 ha) land (equivalent to Nepalese Rupees 4 crores and 22 lakhs in value) for establishing the technical community college dedicated to vocational, agricultural and livestock subjects. Later on, after several rounds of community-level discussions and negotiations, they were able to approach Agriculture and Forestry University (AFU) authority for establishing as one of the branch college, the College of Natural Resources Management $(C N R M)$. Indeed, the community has a dire need, great-spirit, and high 
expectation to contribute to community development and agrarian transformation. Accordingly, campus administration is trying its best to do so. In the long run, there is a great possibility to be established as a newly evolved land grant-community college model.

Similarly, the $A F U$ senate, the highest governing council has decided to establish such branch colleges in different geographical areas and it is in the inception process. This is the time to reality check and monitor their additional obligations towards community and diversity. Additionally, it should be properly monitored to provide its services to communities as an outreach and extension program.

- Institute of Agriculture and Animal Science, Tribhuwan University Institute of Agriculture and Animal Science (IAAS) has a Directorate of Extension and newly established Research and Community Development Center under Lamjung Agriculture Campus to provide services to local communities. The campus has been organizing different workshops and programs to bring together the academician, community and the local bodies for enhancing the community sentiment of the campus and make it more responsible towards the community that sustains it.

- Council for Technical Education and Vocational Training The concept of Council for Technical Education and Vocational Training (CTEVT) seems to have envisioned the idea of community outreach. Conceptually, the CTEVT has established technical and vocational institutes in different geographic areas based on feasibility and potentialities of each geographical area like Humla, Jumla, Mustang, Dang, Seti, Jiri, Lahan, Dhankuta technical institutes. Each institute has its community relations and services to different forms.

- Kathmandu University Technical Training Center, Kathmandu university

Kathmandu University Technical Training Center (KU TTC) is providing services to the community on electric engineering, organic farming, and agriculture. It focuses on mid-level human resources management required for community development.

- High-level Commission for Education of Nepal

A recent commission called High-level Commission for Education of Nepalestablished in 2017 and led by the Ministry of Education (MOE) raises the issues of productive use of the educational system in surroundings (community, society, and state/nation) and transformative education. It also attempts to adopt some key features of the Land-Grant Institutions 1862 and the Land Grant Institutions 1890 (also known as HBCUs) like donating public lands for government schools and colleges, providing funds for improving 
their academic, research and experimental bases etc. in order to bring innovation in various sectors and thus reorienting the education system of Nepal such that the students, professors, researchers of each university and college/campus will research peoples' concerns and their livelihood. Thus, the colleges and universities would transform as the change agents who would learn from the community, teach the community, support the community, enjoy in conjunction with the community and celebrate with the community.

Taking all these together, efforts and services are being provided by existing universities and academic institutions. In the newly evolved federalized context, at least one technical university with technically specialized colleges should be devised to provide their services for the overall development of territory and community by linking education with research and extension for broader transformation process of the society.

\section{Relevancy and Roles of LG and HBC/U-based Provincial Universities and Institutions for Inclusive Agrarian and Rural Transformation in Nepal}

Different academia and political leaders have expressed their views on the relevancy and applicability of Land Grant Institutions and Universities for inclusive

agrarian

transformation

in

Nepal.

A short briefing with the former Vice-chancellor of AFU, Dr. Ishwari Prasad Dhakal brought in limelight the role of the universities under landgrant model in policy making and science-based evidence/inquiry to inform decision makers about the contemporary needs at community and national levels and evaluate and disseminate information to general public. He stated that there are weak horizontal functional linkages between the responsible bodies for agricultural research, extension and education services i.e. National Agricultural Research Council (NARC), Department of Agriculture (DoA) and Department of Livestock Services (DLS) under Ministry of Agriculture and Livestock Development (MOALD) and AFU and other agricultural institutions under Ministry of Education. The weak linkages between these responsible bodies has resulted in the inter-institutional conflicts over resources, funding, priorities and relationships. Land Grant model re-strengthens this linkage by having direct connection at federal level and establishing the significant interrelation among research, extension and educational institutions at different levels (federal, province and local).

Prof. Kailash Nath Pyakurel, the first Vice-Chancellor of the AFU, mentioned that LGU model seems to be different than as understood in Nepalese context in a sense that it is demand based from farmer i.e. farmers 
donated land to university for exchanges of technical expertise and services to people, keeping the routine works of teaching, research and extension regular. The model is purely community based as seen in the case of Agriculture and Forest University's constituent College of Natural Resource Management (CRNM), Puranchaur where people voluntarily donated the land to the university to establish the agriculture college. In turn, the college provides services to the local people beyond the teaching and research. $\mathrm{He}$ said that Nepal and especially AFU can learn from the instances of Land Grant Model as seen in India, the United States and Netherlands. The successful restructuring of LG model is seen in India, where the responsibilities for higher agricultural education, research, extension and the entire field of agricultural and veterinary sciences were transferred to Indian Council of Agricultural Research (ICAR). Also, the state agriculture universities are autonomous organizations and have wide responsibility for agricultural research, education and extension. The US model calls for the collaborative funding relationship between the provinces, districts and the federal government which requires the involvement of decision-making and oversight authorities including the federal and provincial governments. The teaching and research model employed at Wageningen University in the Netherlands has also been widely successful. He called for the development of an integrated model for Land Grant System in Nepalese context combining the lessons from all these successful cases for high quality and education.

He further stressed that the AFU has not been able to perform its role as pre-eminent as in LGU, due to its current mandate of research, teaching and extension mandate and its current funding mechanisms, structures, policies and relationships that come in conflict with other actors conducting similar activities- particularly NARC, DoA and DLS. He suggested that the provincial universities should overcome these constraints and embrace the integrated model of LG system suitable to our own context. The long-term national objectives of prosperity, sustainable and equitable economic growth and food security could only be achieved when these provincial universities could act as platform to connect research, teaching and extension services from community to federal level through policy and institutional support. The clarification of roles and responsibilities of different actors at different levels, needs and aspiration-based programs of the university and the restructuring of the institutional arrangements and collaboration of provincial university with other actors would ultimately allow it to be an active actor for the inclusive transformation of province and overall nation.

In an interview with the former Chief Minister Prithivi Subba Gurung of Gandaki Province regarding the prospects and modality of the Provincial 
University to be established pursuant to Article 57 (Schedule 6) of Constitution of Nepal 2072, he highlighted major challenges of the existing educational institutions as the inability to address the community issues and poor linkage with the key stakeholders and actors of rural transformation. $\mathrm{He}$ highlighted the fact that there is a need for a university that would meet the need for quality academics and compete internationally to establish itself as a leading university amidst these challenges.

As the university is in the inception phase, Mr. Gurung said that the modality of the university would be finalized by a team of experts to meet the need of state's academic requirements. The university, prioritizing more in applied technical science, is supposed to work closely with the community addressing their problems and envisaging solutions thereby maintaining a healthy relationship between them through education, research, and extension. He assured the university to be free from political influence, though political supervision might be given to ensure its effective function. The provincial government would act as a guardian or patron rather than having a direct influence on the university. The curriculum would be such to address the catchment community needs and contemporary issues of the state and quality recruitment of professionals will be done to maintain its competence to the international level.

Regarding the role of the university in rural transformation, Chancellor Ganesh Man Gurung of Gandaki University said that the university would focus on an equitable approach to include backward and marginalized groups to create maximum opportunities for them and ensure the investment and support from key stakeholders. Upon questioning about the relevancy of tribal colleges and Universities like HBC/Us in the context of Nepal, he said that, though typical tribal colleges focusing on certain tribes and groups are out of context at present, he assured that these groups would get equal opportunities to participate in the university through rewards and scholarship programs. He also prioritized that the university would have a community-based educational system and recognition of wider role beyond increasing production and productivity in agriculture, also addressing formal and informal learning needs of actors in the entire chain of development by linking the agriculture with other disciplines and sciences. The students will be motivated to develop a close relationship with these communities and help them solve their local needs and problems through research and extension functions. New academic area and technologies are to be enhanced as an upgrade to conventional disciplines that delivers the need for rural transformation through academic excellence, as measured through innovations they bring to the societies. Finally, an important consideration is 
a political and social commitment by communities, societies, political parties, and countries that are in the catchment of the university. These actors will be encouraged to provide the necessary investment, support, leadership, and policies in the transformation of the university to take up new roles in transforming agricultural systems that benefit their development and pursue academic excellence.

The educationist and former registrar of Far-Western University Prof. Dr. Hemraj Pant opined that for visible development and transformation, the extension sector of the university must be strong and include an exhibition, technology transfer, and reciprocal relationship. It should earn the trustworthiness of the community/society towards academic institutions, however, the educational institutions are lagging behind in community relations and thus are no longer concerned for community service. This has shifted the students' attitude towards education focused on certification rather than developing insights on social issues, which is limiting learning processes (Pant, 2018). Also, the Former VC of Far Western University Prof. Jai Raj Awasthi stressed that there is need of decentralizing the authority of the University at different locations for participating and working in real societal issues upon which they very exist. The decentralization would strengthen their public relations with the community and they could design the strategic plan of the university based on the societal issues of natural and cultural heritage conservation and promotion, medicine processing and marketing facilities, labor mobility, migration issues and other feasible areas for transformation.

In the discussion on how local government can work with agriculture institutions for agrarian transformation, the representatives from Province 7 said that the local level could take benefit from this type of agriculture institution. Local-level registered farmers group can take training and other knowledge help and functions from it. As the farmers in the province are devoid of the improved knowledge and technologies on agriculture practices, the university in cooperation with the local level can do their research on how to improve the agriculture practices of particular communities. The local government, through collaboration with community committee, has donated the grant equivalent to NPR 650,000 to start Intermediate Science (I. Sc.) in Agriculture in the province for the same. It is believed that through donation, communities have shown ownership towards the academic program, and it is the turn of the Agriculture College to fulfill their accountability towards the community. In line with this, the political leaders in province 7 are very interested in the establishment and development of such institutions but their ideas on how to establish such effective institutions and develop the existing 
ones into the efficient ones are lacking. Karnali Province assembly member Jiban Bahadhur Sashi shared the province's vision of establishing a university in the provision which would comprise the applied and technical sciences and extend the programs beyond the confinement of formal university education to community through trainings, exhibition and fairs, seminars etc. The university would also work for documentation of the Indigenous Technical Knowledge; combining and refining them through scientific perspectives and help local people solve their problems through local means and resources through such reformed and locally available resources and knowledge.

Kakkad (2017) highlights the need of combining the curricular offerings and extra-curricular activities by the universities and educational institutions (as in the University of San Diego) which provides students with the solid understandings of the complexities of global challenges. It provides them opportunities to dive deeper into the specific challenge of their choice, thus allowing them (students from different academic disciplines) to come together and engage with the community welfare as active contributors rather than being passive observers and develop insights about the societal issues regarding the inequalities, discrimination, poverty and other constraints for inclusive development in students and motivate them to be active contributor in addressing those societal issues coming together with the very society they work on.

There are five major concerns in inclusive agrarian and rural transformation: i) poverty reduction, ii) management of high social inequality, iii) limited capacities of government, iv) broad based growth, and v) well protected social security schemes (National Planning Commission, 2016). However, the existing universities and academic institutions have rarely focused on these concerns; rather they focus on theoretical and academic excellence with limited knowledge far from the practical life, thus students are not being able to utilize their knowledge in practice (Raika, 2018).

The need of agrarian transformation in line of these concerns, along with the advocacy of the LGS system for such transformation by different academia and politicians as described above pinpoints the wide prospectus for provincial universities to provide applicable and practice-based knowledge that would allow students to face real-life social issues and enable them to provide effective solutions feasible and sustainable from community level by adapting the LGS model localizing in Nepalese context. As such, they could focus on establishing community as its responsible stakeholders, thereby allowing close interaction between students and farmers, where students could learn from experience of farmers and identify their real problems and farmers would be able to solve their problems from technical assistance from 
students, thus re-establishing the broken relationship of the community with educational institutions as well as develop breakthrough on the limited learning process.

The education institutions maintaining close relationship with the public are more effective in the teaching process (Pant, 2018). However, local people come under secondary priority for identification and prioritization of real issues and problems of the community with university and other professionals often consulted and primarily prioritized for identifying problems (Reyes, 2016). This is the most common mistake. Any approach by university needs to engage a give-and-take relationship with its surrounding community. It is all about truly respecting the community's processes and long term relationship being true to oneself and the community itself, and emphasizing 'with the community' rather than 'for the community'. So, th issues of communities become the study area of an institution and this would ultimately increase the sense of ownership of communities towards the universities, while the immediate issues and concerns of the communities could efficiently be resolved by the universities.

An exemplary illustration in community-institution relationship is seen in the plan of Siddhartha College of Agriculture where the marketing function is integrated along with teaching and extension functions being extended in community level, thus developing entrepreneurship in students and making them a competent human resource who can contribute for rural transformation and agricultural development of their respective communities (Singh, 2018). This model of Siddhartha College is in line with the LG system where both the community and institution act as complement and feel ownership towards each other, and such cooperation will lead to the true practice of LGUs. Furthermore, the agriculture system of Nepal is not pocket/location-specific, thus it leaves small and marginal farmers out of service. The LG institutions and universities could act as platform to learn their issues and uplift their conditions by generating innovative means to address their issues through proper research and extension activities taking in consideration the context of the communities they exist.

Thus, the proposed provincial universities should go side by side to address the social issues like poverty, inequality, disparities, dispossessions etc. and contribute towards societal transformation by making the university responsible towards community development.

Also, in the present inability to create political and social opportunities for the marginalized segments of society to improve their conditions, Martin and Osberg (2015) stated that it is important for the educational institutions and universities to be financially sustainable so that 
their benefits do not solely rely on the constant flow of the subsidies. They suggest that this challenge could be solved if two key features of the existing socio-economic system i.e. the involved actors and the enabling technologies could be changed in accordance with socio-economic equilibrium for targeted beneficiaries permanently. The strong commitment and motivation towards the establishment of university directly engaged with community can lead the institutions to achieve sustainable education and socio-economic equilibrium. But Pant (2018) draws attention to strong management and implementing the body of university including public thinkers/intellectuals to run the institutions on land grant models effectively and stable.

If we put together these scattered initiatives, intentions, and concepts, we see a bigger picture which comes close to the LGU model of the US, which shows a new direction for the provincial universities and existing agricultural academic institutions to make them the active stakeholders for agrarian and inclusive transformation. For this, reforms should be initiated from the school level, building the good coordination among agricultural research, education and extension institutions and the local level, and implementing the joint program at the local level with the local communities in order to sensitize them with respect to their responsibilities on transformational issues and initiatives, thus making them active stakeholders. This would allow their needs, concerns and issues to be resolved technically and efficiently through joint and collaborative efforts of university and community. That way, the university could have a prospect of real contribution for inclusive social transformation.

\section{CONCLUSIONS}

Based on political mandate, commitment, constitutional provisions as well as the aspirations and expectations of the people, political decisions should take into consideration the key aspects of inclusive agrarian transformation. After big political changes, it is the right time to take new political course and decisions for state restructuring based on political mandates and constitutional provisions. As pioneered by Abraham Lincoln, the new state assembly should take initiative to develop their own provincial/state universities for their own inclusive transformation and development.

A Provincial/State university and community based academic institutions can be established as public university accountable to defined territories and communities, building a strong university-community relationship in an agrarian landscape. Provincial/State university should undertake additional responsibilities of research and extension besides teaching and learning functions. Through inclusive constitutional provisions, 
inclusive agrarian transformation, pro-poor agrarian reform, and agricultural resources, governance can be designed based on regional planning and commitment to social diversity and inclusion. Moreover, historical inequity, injustice, social diversity, and inclusion are the key factors to be considered for inclusive democratic participation and agrarian transformation. US Land Grant model will be unique in terms of social inclusion which can be expanded in Nepal's future federal state education system as per constitutional provisions of Nepal.

US land justice best practices such as progressive land tax, land trust, farm land access, sustainable farm protection via state legislative proposals, farm cooperative federation, African American farmers' organization etc. are exemplary illustrations. Based on well demonstrated and validated models, community based inclusive transformation models can be designed and implemented under the leadership of academic institutions in collaboration with local, state and federal government. The models that focus on available natural and human resources, resource governance, indigenous knowledge systems, local initiatives and innovation, and commitment to diversity and culture are known to have a positive effect. The combination of these practices will yield sustainable results.

Following the global best practices and national level initiatives, newly elected political leaders, educationists and social activists have an opportunity to fulfil their political and social desire to transform the society and community via land-grant academic institutions. Such models would be province/state specific (regional/location) and innovative for overall sociopolitical and economic transformation in new federal Nepal.

\section{Suggestion for Provincial (State) Government and Provincial Assemblies}

Efforts made so far are also needed towards integrating education with research and extension for rural transformation as the conventional university education system of Nepal lacks research and extension functions that are important for inclusive rural and agrarian transformation.

Possibilities of Inclusive Agrarian Transformations via the concept of State Land-Grant University should be well-devised and designed for addressing the concerns of inclusive agrarian transformation based on:

i) The needs and aspirations of people and region/geography and constitutional provisions, a state university should be established for regional and community development beyond classical teaching functions. All seven states from No. 1 to 7 should have different specific plans based on the feasibility, 
ii) Bottom-up consultation with political parties and CSOs and community along with the key stakeholders are needed for robust planning for overall territorial development and agrarian transformation,

iii) The concept of regional planning and natural resources, land use planning and defined tenure security and local resource governance are better analyzed based on local needs and interests,

iv) Commitment to diversity and social inclusion: Historical Denial of rights in various dimensions such as social, political, economic, cultural, geography should be at the center of the discussion,

v) Local livelihood and employment opportunities focusing on youth should be emphasized, and

vi) Champions diversity, educational equity and the preparation of individuals who can live and work effectively in an increasingly multicultural and interdependent world should be the priority.

In the newly initiated federalization processes in Nepal, following the Land Grant University model and the concept of Historically Black Colleges from the US and others, there is the potential for establishing a state university that should have additional responsibilities of research and extension besides teaching and learning functions. Also, state universities and community colleges can be better linked with central and state research and extension organs of the government for developing holistic learning and technology transfer for overall inclusive agrarian transformation. It will open new avenues for engagement of academic institutions to better devise the inclusive agrarian transformation model considering diversely marginalized and local communities.

\section{Suggestions for Local Government and College/Campus for Community-Based Transformation}

Based upon review, reflection and learning from global practices of Land Grant Institutions, certain initiatives could be suggested regarding Inclusive Rural Transformation Model for overall community development at local levels in Nepalese context.

The rural extension and community development can be developed as a three-way partnership. The three partners are: i) the land-grant university/college in each state or defined location including rural municipalities or urban municipalities, ii) the federal and state government (through the Ministry and department), and iii) local government (through the rural or urban municipalities and Agriculture Service Centers).

True to this model, extension or community development programs in state or defined part of state can be operated in collaboration with local 
government and aligning with state. Local government can develop the larger framework for community development intervention models in which various non-state actors (e.g. Non-Government Organization, Community based Organizations, Community Forest Users Groups, Water Uses Groups, Mothers Group, Youth Club) can work together following the one-door policies.

Similarly, at local levels in Nepal, various initiatives such as establishing community-based library, educational programs, local food councils, local community land trust for conservation of public land, promotion of peri-urban/urban agriculture, local human right watch, media watch, youth-council and employment initiative, land and food-based justice, anti-corruption monitoring watch etc. can be initiated by colleges and the local government.

To illustrate, given that agriculture is a mainstay of Nepalese rural society, Vision for Local Agriculture for Land and Food Systems can be crafted for overall local development through promoting equitable access to resources, opportunities and services to local communities. This work can be coordinated by diverse, committed and engaged stakeholders from all sectors of the land and food systems. Consideration of local level issues and challenges, institutional support for local agriculture, food, land and associated issues can be done. Farmer land access issues such as regulatory blocks, difficulty accessing wholesale markets, various barriers to entry for young and beginning farmers - which are exacerbated in marginalized communities - require broad and deep response, and strategies in marketing, policy change, incentivizing local purchasing, and opening pathways to agricultural transformation (who have been dispossessed of land or have had unequal access to other resources and opportunities) will alleviate these issues.

Upon an examination of various political parties manifestoes for last local election held in 2017, the major political parties have focused on local land use plans, community-based cooperatives, employment security at the household level, income security, local food security and vision, and healthy and nutritional food for all. Continued political commitments in local election manifestoes can support and speed up the rural agricultural transformation processes at the local level.

For sustainability of the proposed local level plan and institutionalized interventions, provincial assemblies and legislative bodies of rural municipalities can initiate and regulate the local policy-making process via various community-based policies, laws, by-laws (e.g. Land use plan, Natural Resource Management policy, local food vision, etc.) Timely and 
participatory intervention on the part of every entity will be critical to achieving sustainable change. After all, the policies are meant to better the life conditions of general public therefore, active participation of beneficiaries in policy development processes could foster the inclusive transformation processes.

\section{Development of Resources for Sustainability of LG-Type Universities in Nepal}

Finally, the most crucial consideration of establishing LG-type Universities targeted for traditionally oppressed (Dalit), backward and underserved segments of people in Nepal is how these institutions are going to be funded and build in full capacity sustainably. A Nepalese scholar Dr. Drona Rasali ${ }^{1}$ who has first-hand experience of LG Universities of India, Philippines, Canada and the US, over a stretch of over four decades, opines that the triad functions- education, research and extension of these universities are very cost-intensive; especially, the research for generating technologies using capital intensive infrastructure and operational capacity (modern farms, farm mechanization, laboratories including biotechnology) needed for advanced research on optimizing crop and livestock production can be very expensive even in those developed countries and can be cost-prohibitive for the resource poor country like Nepal. This is one of the reasons why AFU has not been able to generate substantive technologies to boost agriculture production, despite its more than five decades of its central campus in operations and has been limited largely to teaching. Though federal and state governments in the US contributed to $100 \%$ of LGU funding through various Acts (e.g. Hatch Act, 1862 for research funding) in the US (Allen and Esters, 2018), the subsidies and grants from the public sector alone would not be adequate for sustainable operations of these Universities in the US in the present day costs and LGU R\&D needs, while large research grants are provided by charities of multi-billion corporate giants like Bill and Melinda Gates Foundation, Rockefeller Foundation. In addition to major charity grants, other private corporations that need their technologies to be generated through R\&D in the LG Universities can fund directly to the research teams generating technologies. The non-governmental sector funding of agriculture and food

\footnotetext{
${ }^{1}$ Dr. Rasali was educated in Land Grant type Agricultural Universities in India, the Philippines and Canada for his undergraduate, master's and doctoral degrees respectively, served as professional and senior scientist for little over two decades, and is currently an advisor to the Association of Nepalese Agricultural Professionals in Americas (NAPA).
} 
research in the US was 52\% in 2013 (CRS, 2019). Nepal is currently far from this situation now. However, the federal government that has constitutional obligation (see Nepal Constitution 2015) for providing free higher education especially to Dalits, can seek bilateral and multilateral funding from international communities for building initial infrastructure of LG Universities targeting Dalits and other disadvantaged population as their beneficiaries. The provincial governments can create initial stimulus operational funds along with the research mandate given to these Universities to initiate R\&D. Universities in turn must develop their own sustainability plan to develop private sector that can progressively finance the research in the Universities. Considering that Nepalese agriculture largely is comprised of a smallholder farming system with extreme limitation of land space for farming in large scale, Provincial LG Universities should be given the mandate of organizing Cooperative Extension pooling together smallholder farmers such that they develop a province-wide farmers' Cooperatives. These cooperatives in turn progressively develop their capacity for receiving extensions services and operationalize marketing of small farmers' produces to make a scale of economy. The cooperatives eventually will need generation of new technologies to optimize agricultural production in the united front of the small producers and will develop capacity to fund the research as well in the long term for sustainability of their agriculture.

\section{REFERENCES}

Allen, B.C.M \& Esters, L.T. (2018). Historically Black Land-Grant Universities: Overcoming Barriers and Achieving Success. Research Brief. Center for Minority Serving Institutions, University of Pennsylvania. https://cmsi.gse.rutgers.edu/sites/default/files/HBLGUs_0.pdf\#: :text=Des pite $\% 20$ legislation $\% 20$ that $\% 20$ awarded $\% 20$ funding $\% 20$ to $\% 20$ landgrant $\% 20$ universities,HBLGUs\%20received\%20far\%20less. $\% 20 \% 28 \mathrm{Com}$ er\%20et\%20al.\%2C\%202006\%29.

A New England Food Mission (2014). Food Solutions New England. https://www.foodsolutionsne.org/sites/default/files/LowResNEFV_0.pdf

Brandies. (2018). International Center for Ethics, Justice and Public Life. Brandies University. https://www.brandeis.edu/ethics/

Central Bureau of Statistics. (2011). Nepal Living Standard Survey 3, Volumes I and II. Kathmandu: Central Bureau of Statistics, National Planning Commission, Government of Nepal. 
Central Department of Sociology/Anthropology, Tribhuvan University (2014). The Nepal Multidimensional Social Inclusion Index: Diversity and Agenda for Inclusive Development.

https://idsn.org/wp-content/uploads/2014/12/Nepal-Inclusion-IndexTribuvan.pdf

Council of Ontario Directors of Education. (2014). Equity and inclusive education: Going deeper. The Council of Ontario Directions of Education. Canada.

Congressional Research Service (2019). The U.S. Land-Grant University System: An Overview. https://crsreports.congress.gov/product/pdf/R/R45897.

ENACT. (2018). Engaging students in state government: one college at a time. Pdf available at: http://www.brandeis.edu/ethics/pdfs/ENACTTestimonials.pdf. Retrieved on: $23^{\text {rd }}$ July, 2018.

Frankfurt School. (2009). Encyclopedia Britannica. Available at: www.britannica.com/EBchecked/topi/217277/Frankfurt-School.

FSVU. (2012). FSVU research, 2012. Available at: https://www.yumpu.com/en/document/read/27514854/fvsu-researchreport-2012-fort-valley-state-university

Giménez, E. H. \& Shattuck, A. (2011). Food crises, food regimes and food movements: rumblings of reform or tides of transformation? The Journal of peasant studies, 38 (1),109-44.

Hoefer, A. (2004). The Caste Hierarchy and The State in Nepal: A Study of MulukiAin of 1854. Himal Books.

Holt-Giménez, E. \& Wang, Y. (2012). "Reform or Transformation? The pivotal role of food justice in the U.S. food movement." Race/Ethnicity: Multidisciplinary Global Contexts. The Kirwan Institute for the Study of Race and Ethnicity. Ohio State University.

Jaishi, M., Nepali, P.B. \&Shahi, L. (2018). Agricultural Extension in Nepal under Federalism. AESA Working Paper 2018-005.

Jaishi, M., Nepali, P.B., Rijal, S., \&Dhakal, B. (2020). Strengthening ResearchEducation Extension (R-E-E) Linkage in New Context of Federal Structured Nepal. Responsible Education, Learning and Teaching in Emerging Economies, 2(1), $1-11$.

Justins M. \& Holt-Giménez, E. (2017). Land Justice: Re-imagining Land, Food, and the Commons in the United States, Oakland: Food First.

Kakkad, A. (October 13, 2017). Achieving the Sustainable Development Goals: What can a university do? Kroc Peace Magazine, 31-33. file:///Users/muhammadsharifuddin/Downloads/KROC-MAG-2017final.pdf 
MANRSS. (2018). Minorities in Agriculture, Natural Resources and Related Sciences. Official website. Available at: https://www.manrrs.org/who-we$\underline{\text { are }}$

Martin, R.L. \&Osberg, S.R. (2015). Two Keys to Sustainable Social Enterprise. Havard Business Review: 87-94.

National Institute for Research and Training \& Americal Institute of Research. (2017). Nepal education sector analysis. Kathmandu, Nepal.

NPC. (2016). Envisioning Nepal 2030. Proceedings presented at International Seminar on $28^{\text {th }}$ March, 2016.

Pant, H.R. (2018). Personal Communication on Land Grant Universities and Its Roles in Nepal. Dhangadi, Kailali.

Pyakuryal, K.P. \&Upreti, B.R. (2011). Land, Agriculture and Agrarian Transformation. Kathmandu: Consortium for Land Research and Policy Dialogue (COLARP).

Raika, T.B. (2018). Personal Communication on Land Grant University and Institutions' Suitability in Nepal. Dhangadi, Kailali.

Regmi, K.D. (2019). Higher Education in Nepal: A Handmaiden of Neoliberal Instrumentalism. University of British Columbia, Canada.

Reyes, R. (2016). Engaged Pedagogy: Reflections from a Barriologist. Engaging Pedagogies in Catholic Higher Education: Vol.2 (1), Article 1. Available at: Shttp://journals.stmarysca.edu/epiche/vol2/iss $1 / 1$

Singh, T. B. (2018). Personal Communication on Land Grant University and Institutions' Suitability in Nepal. Dhangadi, Kailali

University of San Diego. (2018). KROC Annual Magazine, 2017/18. Available from: https://issuu.com/universityofsandiego/docs/kroc-mag-2017-final

UMASS. (2018). Center for Agriculture, Food and Environment. University of Massachusetts. Available at: https://ag.umass.edu/about-the-center-foragriculture-food-and-the-environment

PURNA BAHADUR NEPALI, Ph.D. is Associate Professor, and Program Director, Master of Public Policy and Management (MPPM), Kathmandu University School of Management (KU SOM), Balkumari, Lalitpur. Dr. Nepali is Research Fellow (nonresident), Harvard Kennedy School and Hutchins Center, Harvard University, US where he is undertaking his research on Political Economy of Inclusive Agrarian Transformation: Comparative Analysis of Race-Caste of US and Nepal/South-Asia. He has completed his Fulbright Visiting Research Fellowship (2017-18) at Heller School for Social Policy and Management, Brandeis University, USA. His research was on Reorienting Political Economy of Agrarian Transformations, focusing on marginalized communities in Nepal. For the past decade he has researched land rights and food rights, and advocates for evidence-based policy and reform in South Asia 
from a civil society perspective. In addition, he teaches/supervises graduate courses for masters and $\mathrm{PhD}$ students as an adjunct professor at the Tribhuvan University and the Agriculture and Forestry University in Nepal. As a lead editor of the Journal- New Angle, he recently edited a special issue of the peer reviewed article called Agrarian and Land Issues.

He can be assessed at purna@kusom.edu.np, kumar2034@gmail.com , pnepali@g.harvard.edu.

UTTAM GAULEE, Ph.D. is the President of STAR Scholars Network and the founding editor of the Journal of Underrepresented \& Minority Progress. He is a scholar of international higher education. His research interests include community college systems, diaspora studies, interdisciplinary perspectives on education policy, global citizenship, and cross-cultural issues in international development and geopolitics. A professor in the Community College Leadership Doctoral Program at Morgan State University, Dr. Gaulee is an advocate of community college as a vehicle for social progress and economic development in and beyond the U.S. Dr. Gaulee has devoted two decades of his academic and professional life promoting solutions related to student success, workforce development, and institutional effectiveness. While serving as program director of the Community College Futures Assembly and Bellwether College Consortium during 2015-16, he collaborated with multiple national commissions and councils of the American Association of Community Colleges (AACC) to evaluate and promote best practices among community colleges and hosted national policy summits on workforce development, reverse transfer, and talent pipeline management. Email: uttam.gaulee@ morgan.edu.

PRAKASH BARAL is Agricultural Extension Officer, Horticulture Development Resource Center, Ministry of Land Management, Agriculture, Cooperatives and Poverty Alleviation, Gandaki Province, Nepal. Previously, he was serving as Assistant Professor in Jibika College of Agricultural Sciences under Department of Agriculture Extension and Rural Sociology. He has been engaged in different researches related to agriculture, land reforms, policy reforms and agrarian issues. He can be assessed at pra.brl38742@gmail.com.

SUWAS PAUDEL is Agriculture Officer in Value Chain Development Project, Nepal.

SANTOSH KHANAL is an Assistant Professor in Institute of Agriculture and Animal Science, Nepal under the Department of Extension and Rural Sociology/Tribhuvan University. 